https://nv.nltu.edu.ua

https://doi.org/10.36930/40310106

@ $\square$ Correspondence author

Article received 15.01.2021 p.

Article accepted 04.02.2021 p.

O. Ye. Galevych

UDC 712.253(477.53)

oksana.galevich2019@gmail.com

о. Є. Галевич, М. І. Сорока

Національний лісотехнічний університет Украӥни, м. Львів, Украйна

\title{
БІОМОРФОЛОГІЧНИЙ АНАЛІЗ КУЛЬТИВОВАНОЇ ФЛОРИ ПЛОСКИХ ЗЕЛЕНИХ ДАХІВ МІСТА ЛЬВОВА
}

Досліджено біоморфологічні характеристики культивованих видів рослин, ідентифікованих на 24 озеленених плоских дахах екстенсивного типу у Львові. Встановлено, що для створення рослинних композицій використано 225 видів, 136 культиварів, 14 гібридів із 55 родин та 143 родів. Здійснено біоморфологічний аналіз культивованої флори, складеної із 326 видів, гібридів та культиварів, які успішно акліматизувалися на дахах і ростуть на них більше двох років. Проаналізовано спектри життєвих форм, виділених на основі різних класифікаційних систем із застосуванням різних морфологічних критеріїв. Встановлено взаємозв'язок між життєвістю рослини і їі біоморфологічними характеристиками та зроблено висновки про доцільність використання певних біоморф для озеленення покрівель. За класифікацією життєвих форм I. Серебрякова (1962), основним критерієм для виділення життєвих форм вважають довговічність скелетних осей, що є проявом адаптивної реакції рослини на умови середовища. Наші дослідження підтвердили успішність адаптації на дахах багаторічних рослин із здерев'янілими чи підземними метаморфізованими органами, серед них кущі (116 видів; 35,6 \%), полікарпічні трави (107; $32,9 \%$ ) та дерева (43; 13,2 \%). За системою С. Raunkiaer (1934), основою для виділення клімаморф є захист бруньок поновлення та апікальних меристем пагона. За нашими спостереженнями, на дахах більше двох років витримують рослини із добре захищеними бруньками - це 102 види листопадних і 65 вічнозелених фанерофітів $(51,2 \%$ від загальної кількості), гемікриптофіти $(27,6 \%)$ із захищеною опадом рослини і снігом верхівковою брунькою та криптофіти-геофіти (14,2 \%) із схованими глибоко під землею бруньками. Згідно зі системою R. Whittaker (1970) біоморфи рослин $є$ результатом ценотичної взаємодії видів в екосистемах, а умови середовища визначають тип надземних органів рослин, що підтверджено і нашими дослідженнями. Кожен із органів рослин, а також всі окремі ознаки біоморф перебувають у тісному взаємозв'язку із умовами середовища, а тому на дахах найкраще виживають широколисті листопадні дерева $(24 ; 7,4$ \%), широколисті листопадні кущі (71;21,8 \%), та різнотрав'я (72; 22,3 \%). За лінійною системою життєвих форм В. М. Голубєва (1972), біоморфологічні ознаки рослин можна оцінити незалежно одна від одної без виділення життєвих форм, проте кожна окремо взята ознака відображає тип пристосування рослини до умов середовища. Встановлено, що для зелених дахів найбільш характерні кущі $(116 ; 35,6 \%)$, літньозеленого типу $(220 ; 67,5 \%)$, безрозеткові $(324 ; 99,4 \%)$, із змішаною кореневою системою $(219 ; 67,2 \%)$, без виражених підземних кореневищних структур (265; $81,3 \%$ ). Встановлено, що на дахах висотних будівель найкращу життєвість мають низькорослі листопадні кущі та сукуленти. Вище 20 м для здешевлення догляду саду взимку варто ширше застосовувати однорічні рослини. Натомість на дахах недоцільно використовувати такі біоморфи як цибулинні ефемероїди, стрижнекореневі рослини, види із здерев'янілими кореневищами, а також вічнозелені широколистяні види та хвойні 3 ламкими гілками.

Ключові слова: культурфітоценоз; озеленення; екстенсивний дах; екобіоморфа; клімаморфа.

\section{Вступ}

Підтримання високого рівня фіторізноманіття завдяки культивованим видам у сучасних міських агломераціях є важливим завданням озеленювачів з огляду на погіршення умов життя людей за умов посилення техногенного забруднення середовища та зменшення площ зелених насаджень. Проблему нестачі зелених насаджень у місті частково можна вирішити внаслідок озеленення покрівель, що одночасно стане одним із сучасних взірців міської архітектури. Оскільки рослинність відіграє провідну роль у стабілізації параметрів міського середовища, добір придатних для озеленення видів з ви- соким ступенем життєвості та витривалості зумовлює довговічність та якісне функціонування рослинних композицій будь-яких насаджень. Однією із найважливіших ознак активного пристосування рослини до умов довкілля є іiі життєва форма, яка виробилася у процесі довгого еволюційного розвитку організму і має відбитки фітоісторичних подій та генетичних процесів, які стали визначальними для формування цієї екобіоморфи. Водночас життєва форма $є$ відображенням сучасних грунтово-кліматичних і ценотичних умов росту рослини, негативних і сприятливих чинників довкілля та одним із показників успішності адаптації виду до умов середовища [26]. Як-

\section{Інформація про авторів:}

Галевич Оксана Євгеніївна, аспірант, кафедра ботаніки, деревинознавства та недеревних ресурсів лісу. Email: oksana.galevich2019@gmail.com

Сорока Мирослава Іванівна, д-р біол. наук, професор, кафедра ботаніки, деревинознавства та недеревних ресурсів лісу. Email: myroslava_soroka@yahoo.com; https://orcid.org/0000-0002-1037-6904

Цитування за ДСтУ: Галевич О. Є., Сорока М. І. Біоморфологічний аналіз культивованої флори плоских зелених дахів міста Львова. Науковий вісник НЛтУ України. 2021, т. 31, № 1. С. 37-41.

Citation APA: Galevych, O. Ye., \& Soroka, M. I. (2021). Biomorphological analysis of cultivated flora on flat green roofs of the city of Lviv. Scientific Bulletin of UNFU, 31(1), 37-41. https://doi.org/10.36930/40310106 
що йдеться про культивовані рослини, а особливо висаджених у специфічних умовах (наприклад, на озеленених покрівлях), оцінити відповідність їх життєвих форм середовищу дуже складно. Частково це можна зробити шляхом моніторингових спостережень за рослинами, які адаптувалися й успішно ростуть декілька років на одному місці. 3 огляду на це основною метою наших досліджень стало вивчення біоморфологічних характеристик рослин, використаних для озеленення плоских зелених дахах екстенсивного типу в умовах Львова, які ростуть на даху понад два роки.

Об'єкт дослідження - культивована флора плоских зелених дахів екстенсивного типу в умовах Львова.

Предмет дослідження - біоморфологічна структура культивованої флори плоских зелених дахів.

Мета роботи - встановити видовий склад та здійснити біоморфологічний аналіз культивованої флори зелених дахів екстенсивного типу в умовах Львова.

Для досягнення зазначеної мети визначено такі основні завдання дослідження:

- встановити біоморфологічні характеристики культивованих видів рослин на плоских екстенсивних зелених дахах Львова;

- виявити залежність між біоморфами рослин та їх життєвістю на озеленених покрівлях;

- запропонувати методи підбору видового складу для плоских зелених дахів на основі біоморфологічних характеристик видів;

Наукова новизна отриманих результатів дослідження - вперше проаналізовано біоморфологічну структуру культивованої флори плоских зелених дахів у Львові та виявлено закономірності формування стійких рослинних композицій в разі використання конкретних біоморф.

Практична значущість результатів дослідження вони дадуть змогу максимально правильно формувати функціональні екосистеми зелених дахів на основі характеристик життєвих форм рослин.

Аналіз останніх досліджень та публікацій. Для створення стійких і довговічних композицій на озеленених покрівлях надважливе значення мають дослідження морфологічних ознак рослин та їх клімаморф. Доведено, що на дахах найкраще виживають види, які природно ростуть у подібному середовищі, що свідчить про доцільність застосування відповідних біоморф для формування зелених дахів. При цьому необхідно добирати види, здатні тривалий час співіснувати разом $[18,25$, 30]. Дослідження біоморф рослин на зелених дахах довело, що композиції, створені із вічнозелених та широколистих квітучих трав мають значні переваги порівняно із угрупованнями низькорослих злаків. Дослідження рослин різних біоморф (сукуленти, високорослі рослини, карликові кущі, повзучі рослини, злаки) порівняно iз насадженнями рослин однієї життєвої форми довело позитивний зв'язок між біорізноманіттям культивованої флори та екосистемними функціями даху [7, 15, 22, 27, 33]. На дахах переважно використовують сукуленти роду Sedum, які здатні виживати в суворих умовах зеленого даху, проте дедалі частіше для озеленення покрівель використовують мохоподібні як компоненти в угрупованнях судинних рослин. Деякі види трав'янистих рослин мають покращені показники росту тільки в поєднанні з мохоподібними, оскільки мохи активно знижують температуру грунту [10]. Під час створення зелених дахів потрібно врахувати поведінку рослин на дахах, зокрема, їх неконтрольоване поновлення. Виявлено, що низькорослі злаки на даху перешкоджають проростанню насінин небажаних видів, зменшуючи їх контакт із землею [21]. Останні розробки у галузі озеленення покрівель свідчать про необхідність створення цілих екосистем на даху 3 високими показниками стійкості рослинного вкриття, що можна досягнути тільки внаслідок добору видів відповідних біоморф. Досліджено, що функціонування зелених дахів контролюється не тільки окремими видами, а й їх угрупованнями, а тому характеристика рослинності зелених дахів $\epsilon$ способом відбору видів для зелених дахів $[2,16,17]$. Ефективним прийомом є застосування видів різних біоморф із фенологічними відмінностями росту, що посилює естетичні характеристики та продовжує термін зелених дахів [9, 32].

Матеріали та методи дослідження. Дослідження біоморфологічних характеристик рослин 24 плоских зелених дахів екстенсивного типу в умовах Львова здійснювали впродовж 2016-2020 рр. Для обстеження висотних об'єктів застосовували безпілотний літальний апарат - квадрокоптер DJI Mavic 2 Pro (СР.МА.00000013.01). Визначення видів рослин та їх культиварів виконували 3 допомогою спеціалізованих визначників $[1,4,11,12,13,14,20,29]$. Укладено систематичний список культивованої флори на основі лінійних класифікаційних систем: для папоротеподібних PPG I [23], для голонасінних [5], для покритонасінних APG IV [3]. Латинські назви рослин наведено за таксономічною електронною базою даних The Plant List [28]. Життєві форми рослин виокремлено за різними класифікаційними системами [8, 24, 26, 31].

\section{Результати дослідження та їх обговорення}

За результатами інвентаризації видового складу рослин 24 озеленених плоских дахів встановлено, що для їх створення використано 575 таксонів, з них: 225 видів, 136 культиварів, 14 гібридів із 55 родин та 143 родів. До біоморфологічного аналізу залучено 326 видів, гібридів та культиварів. Проаналізовано спектри життєвих форм, виділених на основі різних класифікаційних систем. Для з'ясування доцільності використання асортименту рослин на озеленених покрівлях встановлено взаємозв'язок між життєвістю рослини та її біоморфологічними характеристиками, виділеними на основі різних критеріїв. Так, класифікація життєвих форм I. Серебрякова [26] побудована на оцінюванні морфологічних ознак та довговічності скелетних осей, що $є$ проявом адаптативної реакції рослини на умови середовища. Згідно з цією класифікації, серед рослин, використаних для озеленення дахів, переважають багаторічні рослини, більшість із здерев'янілими чи підземними метаморфізованими органами - кущі $(35,6$ \%), полікарпічні трави (32,9 \%) та дерева (13,2 \%) (табл. 1).

Класифікаційна система C. Raunkiaer [24] опирається на постулат, що головною ознакою, яка відображає пристосування рослин до несприятливих умов, $є$ спосіб захисту бруньок поновлення (а разом з тим й апікальних меристем), та висота їх розташування над землею. Аналізуючи спектр клімаморф рослин зелених дахів, виокремлених на основі цієї системи, зазначимо, що на дахах переважають рослини із добре захищеними бруньками - це 102 види листопадних і 65 вічнозелених 
фанерофітів (51.2 \% від загальної кількості), гемікриптофіти $(27.6 \%)$ із захищеною опадом рослини і снігом верхівковою брунькою та криптофіти-геофіти (14.2\%) із схованими глибоко під землею бруньками (табл. 2).

Табл. 1. Біоморфологічна структура культивованої флори за системою I. Серебрякова [26]

\begin{tabular}{|c|c|c|c|}
\hline $\begin{array}{l}\text { № } \\
\text { 3/ח }\end{array}$ & Життєві форми & \begin{tabular}{|l|} 
Кількість \\
видів, шт
\end{tabular} & $\%$ \\
\hline 1 & Дерева, зокрема: & 43 & 13,2 \\
\hline 1.1 & Високостовбурні & 18 & 5,5 \\
\hline 1.2 & Низькостовбурні & 25 & 7,7 \\
\hline 2 & Кущі, зокрема: & 116 & 35,6 \\
\hline 2.1 & Прямостоячі, геоксильні & 98 & 30,1 \\
\hline 2.2 & Сланкі, простерті & 16 & 4,9 \\
\hline 2.3 & Ліаноподібні & 2 & 0,6 \\
\hline 3 & Напівкущі і напівкущики, зокрема: & 10 & 3,1 \\
\hline 3.1 & Прямостоячі напівкущі і напівкущики & 9 & 2,8 \\
\hline 3.1 & Повзучі напівкущі і напівкущики & 1 & 0,3 \\
\hline 4 & Багаторічні трави, зокрема: & 107 & 32,9 \\
\hline 4.1 & Короткострижнекореневі & 17 & 5,2 \\
\hline 4.2 & Довгокореневищні & 8 & 2,5 \\
\hline 4.3 & Короткокореневищні & 32 & 9,8 \\
\hline 4.4 & Дерновинні, зокрема: & 29 & 8,9 \\
\hline 4.4 .1 & Щільнокущові & 21 & 6,5 \\
\hline 4.4 .2 & Пухкокущові & 8 & 2,5 \\
\hline 4.5 & Надземностолонні & 15 & 4,6 \\
\hline 4.6 & 3 бульбами & 2 & 0,6 \\
\hline 4.7 & Цибулинні & 4 & 1,2 \\
\hline 5 & Однорічні & 4 & 1,2 \\
\hline 6 & Ліани, зокрема: & 15 & 4,6 \\
\hline 6.1 & В'юнкі & 4 & 1,2 \\
\hline 6.2 & Коренелазячі & 3 & 0,8 \\
\hline 6.3 & Вусиконосні & 8 & 2,5 \\
\hline 7 & Сукуленти, зокрема: & 30 & 9,2 \\
\hline 7.1 & Листові, зокрема: & 30 & 9,2 \\
\hline 7.1 .1 & напіввічнозелені & 8 & 2,5 \\
\hline \multirow[t]{2}{*}{8} & Подушкоподібні & 1 & 0,3 \\
\hline & Всього & 326 & 100,0 \\
\hline
\end{tabular}

Табл. 2. Біоморфологічний спектр культивованої флори за системою C. Raunkiaer [24]

\begin{tabular}{|l|c|c|}
\hline Життва форма & $\begin{array}{c}\text { Кількість видів, гібри- } \\
\text { дів та культиварів }\end{array}$ & $\begin{array}{c}\text { \% від заг. } \\
\text { кількості }\end{array}$ \\
\hline Фанерофіти, зокрема: & 167 & 51,2 \\
\hline мезофанерофіти, зокрема: & 22 & 6,7 \\
\hline вічнозелені & 9 & 2,8 \\
\hline листопадні & 13 & 3,9 \\
\hline мікрофанерофіти, зокрема: & 64 & 19,6 \\
\hline вічнозелені & 27 & 8,3 \\
\hline листопадні & 37 & 11,3 \\
\hline нанофанерофіти, зокрема: & 73 & 22,4 \\
\hline вічнозелені & 26 & 8,0 \\
\hline листопадні & 47 & 14,4 \\
\hline деревні ліани & 8 & 2,5 \\
\hline Хамефіти, зокрема: & 19 & 5,8 \\
\hline вічнозелені & 8 & 2,5 \\
\hline листопадні & 11 & 3,3 \\
\hline Гемікриптофіти & 90 & 27,6 \\
\hline Криптофіти & 46 & 14,2 \\
\hline Терофіти & 4 & 1,2 \\
\hline Всього & 326 & 100,0 \\
\hline
\end{tabular}

R. Whittaker [31] трактує біоморфи рослин як результат ценотичної взаємодії видів в екосистемах, а умови середовища визначають тип надземних органів рослин (табл. 3).
Табл. 3. Біоморфологічна структура культивованої флори за системою $R$. Whittaker [31]

\begin{tabular}{|l|c|c|}
\hline Життєва форма & $\begin{array}{c}\text { Кількість видів, гібри- } \\
\text { дів та культиварів }\end{array}$ & $\begin{array}{c}\text { \% від заг. } \\
\text { кількості }\end{array}$ \\
\hline Дерева, зокрема: & 43 & 13,2 \\
\hline Голколисті & 18 & 5,5 \\
\hline Широколистяні вічнозелені & 1 & 0,3 \\
\hline Широколистяні листопадні & 24 & 7,4 \\
\hline Ліани & 15 & 4,6 \\
\hline Кущі, зокрема: & 116 & 35,6 \\
\hline Голколисті & 41 & 12,6 \\
\hline Широколистяні вічнозелені & 3 & 0,9 \\
\hline Широколистяні листопадні & 71 & 21,8 \\
\hline Розеткові & 1 & 0,3 \\
\hline Напівкущі і напівкущики & 10 & 3,1 \\
\hline Трави, зокрема: & 141 & 43,5 \\
\hline Папороті & 1 & 0,3 \\
\hline $\begin{array}{l}\text { Злакоподібні (ситники, осо- } \\
\text { ки, злаки) }\end{array}$ & 68 & 20,9 \\
\hline Різнотравні види & 72 & 22,3 \\
\hline Всього & 326 & 100,0 \\
\hline
\end{tabular}

Помітно, що кожен із органів рослин, а також всі окремі ознаки біоморф перебувають у тісному взаємозв'язку із умовами середовища (табл. 4). Оскільки непридатні для озеленення покрівель види загинули у перший рік експлуатації даху, всі наступні роки спостережень дали змогу виокремити найстійкіші біоморфи та ознаки окремих органів рослин, які дають рослині змогу пережити екстремальні умови. За лінійною системою життєвих форм біоморфологічні параметри рослин оцінюють незалежно одна від одної без виділення життєвих форм.

Табл. 4. Структура культивованої флори за лінійною системою [8]

\begin{tabular}{|c|c|c|}
\hline Ознака біоморфи & $\begin{array}{l}\text { Кількість } \\
\text { видів, шт }\end{array}$ & $\begin{array}{l}\% \text { від заг. } \\
\text { кількості }\end{array}$ \\
\hline \multicolumn{3}{|c|}{ Тип біоморфи } \\
\hline Дерева & 43 & 13,2 \\
\hline Кущі & 116 & 35,6 \\
\hline Напівкущі і напівкущики & 10 & 3,1 \\
\hline Трав'янисті рослини & 111 & \\
\hline Полікарпіки & 107 & 33,4 \\
\hline Монокарпіки & 4 & 0,6 \\
\hline Всього & 326 & 100,0 \\
\hline \multicolumn{3}{|c|}{ Тип вегетації } \\
\hline Вічнозелені & 72 & 22,1 \\
\hline Літньозелені & 220 & 67,5 \\
\hline Літньо-зимовозелені & 30 & 9,8 \\
\hline Ефемероїди & 4 & 0,6 \\
\hline Всього & 326 & 100,0 \\
\hline \multicolumn{3}{|c|}{ Тип надземних пагонів } \\
\hline Безрозеткові & 324 & 99,4 \\
\hline Напіврозеткові & 1 & 0,3 \\
\hline Розеткові & 1 & 0,3 \\
\hline Всього & 326 & 100,0 \\
\hline \multicolumn{3}{|c|}{ Тип кореневої системи } \\
\hline Стрижневокореневі & 103 & 31,6 \\
\hline Стрижнево-мичкуватокореневі & 219 & 67,2 \\
\hline Мичкуватокореневі & 4 & 1,2 \\
\hline Всього & 326 & 100,0 \\
\hline \multicolumn{3}{|c|}{ Тип підземних пагонів } \\
\hline Довгокореневищні & 8 & 2,5 \\
\hline Короткокореневищні & 32 & 9,8 \\
\hline Надземностолонні & 15 & 4,6 \\
\hline Бульбокореневищні & 2 & 0,6 \\
\hline Цибулинні & 4 & 1,2 \\
\hline Без кореневищної структури & 265 & 81,3 \\
\hline Всього & 326 & 100,0 \\
\hline
\end{tabular}

Scientific Bulletin of UNFU, 2021, vol. 31, no 1 
Згідно зі системою В. М. Голубєва [8] для зелених дахів найхарактерніші літньозелені кущі безрозеткового типу із змішаною кореневою системою без кореневищних структур (див. табл. 4).

\section{Висновки}

В озелененні покрівель екстенсивного типу в місті Львові використано 186 видів і культиварів із здерев'янілими стеблами та 140 видів і культиварів із трав'янистим типом стебла. Порівняння біоморфологічних спектрів культивованої флори, сформованих на основі різних класифікаційних систем, дало змогу виокремити стійкі до екстремальних умов біоморфи. На озеленених покрівлях рослина перебуває у критичних умовах, а тому тут виживають переважно фанерофіти (51.2 \% від загальної кількості видів і культиварів), гемікриптофіти (27.6 \%), рідше - криптофіти (14.2\%), оскільки грунт на даху промерзає. На даху висотних будівель найкращу життєвість мають низькорослі кущі та сукуленти, проте під час влаштування композицій на даху варто уникати висадки рослин із стрижневою кореневою системою та здерев'янілими кореневищами, які можуть пошкодити коренеутримувальну мембрану. За нашими спостереженнями, погано переносять мікроклімат дахів також вічнозелені широколистяні види дерев, які обгорають на сонці, а також деякі хвойні види, гілки яких обламує вітер. Не бажано використовувати також цибулинні види-ефемероїди, які можуть прорости під час відлиги взимку. Для озеленення дахів висотних будівель (вище 20 м) доцільно ширше застосовувати однорічні рослини, що здешевить утримання саду взимку.

\section{References}

1. American Conifer Society. (2020). Retrieved from: //www. conifersociety. org.

2. Carlisle, S., \& Piana, M. (2015). Green roof plant assemblage and dynamics. In Green Roof Ecosystems. Springer, Cham, 285-310.

3. Chase, M. W., Christenhusz, M. J. M., Fay, M. F., Byng, J. W., Judd, W. S., Soltis, D. E., Mabberley, D. J., Sennikov, A. N., Soltis, P. S., \& Stevens, P. F. (2016). An update of the Angiosperm Phylogeny Group classification for the orders and families of flowering plants: APG IV. Botanical Journal of the Linnean Society, 181(1), May, 1-20. https://doi.org/10.1111/boj.12385

4. Cheers, G. (2003). Botanica. Das ABC der Pflanzen. Köln: Könemann.

5. Christenhusz, M. J. M., Reveal, J. L., Farjon, A., Gardner, M. F., Mill, R. R., \& Chase, M. W. (2011). A new classification and linear sequence of extant gymnosperms. Phytotaxa : journal, 19, $55-70$.

6. Dobrochayeva, D. N., Kotov, M. I., \& Prokudyn, Yu. N. (1987). Guide to higher plants of Ukraine. Kyiv: Naukova dumka. [In Ukrainian]

7. Farrell, C., Szota, C., Williams, N. S., \& Arndt, S. K. (2013). High water users can be drought tolerant: using physiological traits for green roof plant selection. Plant and soil, 372(1-2), 177193. https://doi.org/10.1007/s11104-013-1725-x

8. Golubev, V. N. (1972). Principles of construction and maintenance of a linear system of life forms of angiosperms, Bulletin of the Moscow Society of Naturalists. Biology dep, 7(6), 72-80. [In Russian].

9. Heim, A., \& Lundholm, J. (2016). Phenological complementarity in plant growth and reproduction in a green roof ecosystem. Eco$\begin{array}{llll}\text { logical Engineering, } & \text { 94, } & \text { 82-87. }\end{array}$ https://doi.org/10.1016/j.ecoleng.2016.05.018

10. Heim, A., Lundholm, J., \& Philip, L. (2014). The impact of mosses on the growth of neighbouring vascular plants, substrate temperature and evapotranspiration on an extensive green roof. Urban
Ecosyst, 17, 1119-1133. https://doi.org/10.1007/s11252-0140367-y

11. Kokhno, M. A. (2001). Dendroflora of Ukraine. Wild and cultivated trees and shrubs. Gymnosperm. Kyiv: Phytosocial Center. [In Ukrainian]

12. Kokhno, M. A. (2002). Dendroflora of Ukraine. Wild and cultivated trees and shrubs. Angiosperms. Kyiv: Phytosocial Center. [In Ukrainian]

13. Kolesnikov, A. I. (1974). Decorative dendrology. Moscow: Lesnaya promyshlennost. [In Russian]

14. Krussmann, G. (1995). Manual of Cultivated Conifers. Portland, Oregon: Timber Press.

15. Lee, K. E., Williams, K. J., Sargent, L. D., Farrell, C., \& Williams, N. S. (2014). Living roof preference is influenced by plant characteristics and diversity. Landscape and Urban Planning, 122, 152-159. https://doi.org/10.1016/j.landurbplan.2013.09.011

16. Lundholm, J., \& Williams, N. (2015) Effects of Vegetation on Green Roof Ecosystem Services. In: Sutton R. (Eds.). Green Roof Ecosystems. Ecological Studies (Analysis and Synthesis), Springer, Cham, vol. 223. https://doi.org/10.1007/978-3-319-14983-7_9

17. Lundholm, J., Heim, A., Tran, S., \& Smith, T. (2014). Leaf and life history traits predict plant growth in a green roof ecosystem. PloS one, 9(6), e101395. https://doi.org/10.1371/journal.pone.0101395

18. Lundholm, J., MacIvor, J.S., MacDougall, Z., \& Ranalli, M. (2010). Plant species and functional group combinations affect green roof ecosystem functions. PloS one, 5(3), e9677. https://doi.org/10.1371/journal.pone.0009677

19. Lundholm, J. T. (2015), Green roof plant species diversity improves ecosystem multifunctionality. Journal of Applied Ecology, 52, 726-734. https://doi.org/10.1111/1365-2664.12425

20. Miller, D. (2008). 400 trees and shrubs for small spaces. Portland: Timber Press.

21. Miller, L. E., Heim, A. E., \& Lundholm, J. (2014). Green roof vegetation type affects germination and initial survival of colonizing woody species. Urban Forestry \& Urban Greening, 13(4), 892899. https://doi.org/10.1016/j.ufug.2014.10.001

22. Nardini, A., Andri, S., \& Crasso, M. (2012). Influence of substrate depth and vegetation type on temperature and water runoff mitigation by extensive green roofs: shrubs versus herbaceous plants. Urban Ecosystems, 15(3), 697-708. https://doi.org/10.1007/s11252-011-0220-5

23. PPG I. (2016). A community - derived classification for extant lycophytes and ferns PPG I. Journal of Sytematics Evolution, 54, 563-603. https://doi.org/10.1111/jse.12229

24. Raunkiaer, C. (1934). The life forms of plants and statistical plant geography. Oxford: Clarendon Press.

25. Rayner, J. P., Farrell, C., Raynor, K. J., Murphy, S. M., \& Williams, N. S. (2016). Plant establishment on a green roof under extreme hot and dry conditions: The importance of leaf succulence in plant selection. Urban Forestry \& Urban Greening, 15, 614. https://doi.org/10.1016/j.ufug.2015.11.004

26. Serebryakov, I. G. (1962). Ekologicheskaya morfologiya rasteniy: Zhiznennyie formy pokrytosemennysh i shvoynyh. Uchebnoe posobie. Moskwa: Vyisshaya shkola. [In Russian].

27. Shafique, M., Kim, R., \& Rafiq, M. (2018). Green roof benefits, opportunities and challenges - A review. Renewable and Sustainable Energy Reviews, 90, 757-773. https://doi.org/10.1016/j.rser.2018.04.006

28. The Plant List. (2020). A working list of all plant species. Retrieved from: http://www.theplantlist.org

29. USSR. (2020). Trees and bushes of the USSR (1949-1962). Vol. 1-6. Moscow-Leningrad: Publishing House of the USSR Academy of Sciences. [In Russian].

30. Van Mechelen, C., Dutoit, T., Kattge, J., \& Hermy, M. (2014). Plant trait analysis delivers an extensive list of potential green roof species for Mediterranean France. Ecological engineering, 67, 48-59. https://doi.org/10.1016/j.ecoleng.2014.03.043

31. Whittaker, R. H. (1970). Communities and Ecosystems. London: The Macmillan Company, Coller Macmillan Limited. 
32. Williams, K. J., Lee, K. E., Sargent, L., Johnson, K. A., Rayner, J., Farrell, C., \& Williams, N. S. (2019). Appraising the psychological benefits of green roofs for city residents and workers. Urban Forestry \& Urban Greening, 44, 126399.
33. Zhang, Z., Szota, C., Fletcher, T. D., Williams, N. S., Werdin, J., \& Farrell, C. (2018). Influence of plant composition and water use strategies on green roof stormwater retention. Science of The Total Environment, 625, 775-781. https://doi.org/10.1016/j.scitotenv.2017.12.231

O. Ye. Galevych, M. I. Soroka

Ukrainian National Forestry University, Lviv, Ukraine

\section{BIOMORPHOLOGICAL ANALYSIS OF CULTIVATED FLORA ON FLAT GREEN ROOFS OF THE CITY OF LVIV}

The biomorphological characteristics of cultivated plant species identified on 24 green flat roofs of extensive type in the city of Lviv have been studied. It was found that 225 species, 136 cultivars, 14 hybrids from 55 families and 143 genera were used to create plant compositions. The authors have conducted a biomorphological analysis of cultivated flora consisting of 326 species, hybrids and cultivars which have successfully acclimatized on the roofs and have been growing on them for more than two years. The spectra of life forms identified on the basis of various classification systems using various morphological criteria have been analyzed. The relationship between the vitality of the plant and its biomorphological characteristics was established and conclusions were drawn about the advisability of using certain biomorphs for greening roofs. According to the classification of life forms by I. Serebryakov (1962), the main criterion for identifying life forms is the longevity of skeletal axes, which is a manifestation of the adaptive response of a plant to the environmental conditions. Our studies confirmed the success of adaptation on the roofs of perennial plants with lignified or underground metamorphosed organs, including bushes (116 species; $35.6 \%)$, polycarpic grasses $(107 ; 32.9 \%)$ and trees $(43$; $13.2 \%)$. According to the system of S. Raunkiaer (1934), the basis for identifying climamorphs is the protection of the reproductive buds and apical meristems of the shoot. According to our observations, plants with well-protected buds can survive on roofs for more than two years - these are 102 species of deciduous and 65 evergreen phanerophytes $(51.2 \%$ of the total), hemicryptophytes $(27.6 \%)$ with plants whose apical buds are protected by litter and snow, and cryptophytes-geophytes (14.2\%) with buds hidden deep underground. According to the system of R. Whittaker (1970), plant biomorphs are the result of coenotic interaction of species in ecosystems, and the environmental conditions determine the type of aboveground plant organs, which is confirmed by our research. Each of the plant organs, as well as all the individual features of biomorphs, are closely related to the environmental conditions, and therefore deciduous broadleaved trees $(24 ; 7.4 \%)$, deciduous broadleaved bushes $(71 ; 21.8 \%)$, and herbs survive best on the roofs. According to the linear system of life forms by V.M. Golubev (1972), biomorphological features of plants can be assessed independently of each other without distinguishing life forms, but each individual feature reflects the type of plant adaptation to the environmental conditions. It was also found that the most typical for green roofs are bushes $(116 ; 35.6 \%)$ of summer-green types (220; $67.5 \%)$, rosetteless $(324 ; 99.4 \%)$, with a mixed root system $(219 ; 67.2 \%)$, without pronounced underground rhizome structures $(265 ; 81.3 \%)$. It has been established that low-growth deciduous bushes and succulents have the best vitality on the roofs of high-rise buildings. Above $20 \mathrm{~m}$, annuals should be used more widely to reduce the cost of garden maintenance in winter. It is not advisable to use biomorphs such as bulbous ephemeroids, plants with a tap-root system, species with lignified rhizomes, as well as evergreen broadleaved species and conifers with brittle branches on the roofs.

Keywords: culture phytocoenosis; greening; extensive-type roof; ecobiomorph; climamorph. 